\title{
Reconnecting art and science for sustainability: learning from indigenous knowledge through participatory action-research in the Amazon
}

\author{
Simone Athavde $^{1}, \underline{\text { Jose Silva-Lugo }}^{2}$, Marianne Schmink $^{3}$, Aturi Kaiabi $^{4}$ and Michael Heckenberger $^{5}$
}

\begin{abstract}
Sustainability science focuses on generating and applying knowledge to environmentally sound human development around the world. It requires working toward greater integration of different types of knowledge, ways of knowing, and between academy and society. We contribute to the development of approaches for learning from indigenous knowledge, through enhanced understanding of the system of values, meanings, and relationships afforded by indigenous arts. We focus on a long-term, participatory action research project developed for the revitalization of weaving knowledge among three Kawaiwete (also known as Kaiabi) indigenous groups in the Amazon. The problem was originally defined by indigenous communities, concerned with the erosion of weaving knowledge of basketry and textiles among men and women. Methods for coproduction of knowledge included dialogical methods and tools, indigenous-led strategies, and quantitative and qualitative approaches across biophysical and social sciences. Longitudinal and cross-sectional studies considered multiple dimensions, scales, and networks of knowledge creation, distribution, and transmission. Innovation and articulation with western systems, along with shamanism, gender, and leadership, were key factors enhancing artistic knowledge resilience. We reflect on lessons learned and implications of this initiative for broadening the understanding of art and science intersections toward a sustainable future.
\end{abstract}

Key Words: indigenous art; Brazilian Amazon; epistemology; inter - and transdisciplinarity; Kaiabi; Kawaiwete; participatory action research; social-ecological resilience; sustainability; weaving knowledge

\section{INTRODUCTION}

Sustainability science is an emerging approach concerned with producing and applying knowledge that is relevant for achieving human well-being while protecting the Earth's life support systems for future generations (Kates et al. 2001). Sustainability challenges require new forms of knowledge production and integration within and beyond academic disciplinary fields across the humanities and the biophysical, formal, social, and applied sciences, as well as other nonacademic knowledge domains, such as indigenous knowledge and policy making (Martens 2006, Lang et al. 2012). A key aspect of this engaged knowledge field is the involvement of actors outside academia in the research process, creating a shared understanding of social-ecological systems and exploring innovative approaches for learning, and producing knowledge that is relevant, credible, and legitimate for local communities, scientists, practitioners, and decision makers (Gibbons et al. 1994, Kates et al. 2005, Reed et al. 2010, Lang et al. 2012).

According to Martens (2006), approaches informing sustainability science have included analytical, participatory, and managerial methods. Participatory approaches articulating academic and local or societal knowledge for sustainable development started in the field of rural development and adult education, and since then have taken many forms and directions, including collaborative research and participatory action research (PAR; Freire 1970, Chambers 1994, Probst et al. 2003). Participatory research emerged in the 1960s and 1970s as a critical approach in adult education in the geographic South, particularly in Africa, Asia, and Latin America, focusing on the importance of learning and organizing as vehicles for empowerment. It grew as a reaction to positivistic and empiricist philosophical systems, attempting to find ways of uncovering knowledge that worked better for societal needs (Chambers 1994, Etmanski and Pant 2007).

Within participatory development, the participatory action research approach is developed through collective inquiry and experimentation grounded in experience and social history. It emphasizes collective participation and action, in which core searchers seek to understand the world by collaboratively trying to change it, sharing research methods, learning, and by building mutual capacity (Reason and Bradbury 2008, Long et al. 2016). Participatory research as a philosophy for articulating scientific and societal knowledge in sustainability science faces many challenges. Questions of who defines the agenda for research, ethics, power differentials in knowledge production and appropriation, ownership and identity of the research project, and the political and financial dimensions of the research process and outcomes need to be addressed (Edwards et al. 2008, Mariella et al. 2009, Athayde et al. 2016).

In parallel with the emergence of participatory approaches for integrating scientific and societal knowledge in sustainability science, in the 1970s, psychologist Jean Piaget coined the term "transdisciplinary," referring to an epistemological paradigm that enables the transcendence of academic disciplines, in which the relationship among them would be situated in a totalizing system, without stable borders (Nicolescu 2010). More recently, scholars have employed the term transdisciplinary as a principle for joint knowledge production between science and society in the resolution of societal problems (Tress et al. 2006, Lang et al. 2012). In principle, the transdisciplinary approach would enable the appreciation of other ways of knowing and diverse ontological worldviews, contributing to raise awareness toward resolving issues of power and dominance of western science over other

\footnotetext{
${ }^{1}$ Tropical Conservation and Development Program, Center for Latin American Studies, University of Florida, ${ }^{2}$ Academic Technology, University of Florida, ${ }^{3}$ Center for Latin American Studies, University of Florida, ${ }^{4}$ Associação Indígena Tapawia, Brazil, ${ }^{5}$ Department of Anthropology, University of Florida
} 
knowledge systems, be they indigenous, afro-descendent, or simply local (Santos 2007). Transdisciplinarity does not necessarily employ participatory approaches and methods in its practice and might not aim for community empowerment (Klein 2008).

There is widespread recognition that indigenous knowledge systems (IK) are vital components of environmental management, biodiversity conservation, and sustainability (Gadgil et al. 1993, Berkes et al. 1994, Heckenberger et al. 2007, Pretty et al. 2009). Nonetheless, practical and conceptual bridges between indigenous peoples, scientists, politicians, and society at large in knowledge production, sharing, and integration are often poorly developed, although all aim toward coexistence in an interconnected world (Raymond et al. 2010, Bohensky and Maru 2011). Berkes and Berkes (2009) remind us that what science designates as "indigenous knowledge" is rooted in a different worldview than western science and, as such, works under different starting points, assumptions, and rules. Brosius (2004) highlighted questions of representation of what is considered "local," because IK is often mediated by researchers who speak on behalf of indigenous peoples in national and international venues. He adds that scientists who focus attention solely on ecological knowledge typically ignore other domains, as if they were separated from the local context of IK and its applications in environmental management.

We contribute to the development of transdisciplinary approaches for learning from indigenous artistic knowledge in research actionable for sustainability. The empirical example we explore focuses on a long-term action-research project carried out among three Kawaiwete indigenous groups in the Brazilian Amazon, aimed at the revitalization of artistic knowledge of basketry and textiles among men and women. According to van Velthem (2003), any indigenous object which integrates the larger material culture system might be considered a work of art for its aesthetic and technical qualities. Chernela (2008) argued that material culture objects may work as signifiers of history, or as agents in the construction of history, having consequences in the social and political life of indigenous peoples. The objects bring with them a web of meanings, reflecting aspects of the ecology, economy, and the lifestyle of indigenous peoples (Ribeiro 1987). They can work as stimuli upon which human societies reflect and restate their culture, through material and symbolic representations (Ribeiro 1987, Ross 2004).

For this analysis, weaving knowledge, and associated ways of knowing, symbolic meaning, and management practices were approached as social-ecological practices. Topics including ontologies (study of categories of beings and their existence), collective memory, learning and knowing pathways, ethnoecology, use and management of natural resources employed in weaving, as well as knowledge distribution and intergenerational change, were studied through inter and transdisciplinary approaches in collaboration with four Kawaiwete communities over an eightyear time frame.

\section{METHODS}

\section{Study site}

The Kawaiwete (recent self-designation, also known as Kaiabi) are a Tupi-Guarani speaking people who originally occupied several tributaries of the Tapajós River in the southern Brazilian Amazon. Between 1950 and 1966, the Brazilian federal government forced the relocation of the majority of the group to what is now the Xingu Indigenous Park (PIX). Although most people relocated to Xingu, two smaller groups resisted and live close to their ancestral regions, one on the Dos Peixes River and the other along the Teles Pires River (Fig. 1).

Fig. 1. Map showing the location of the study area, including three Kawaiwete (Kaiabi) lands in the Amazon: Xingu Indigenous Park, TI Kayabi in the Teles Pires River, and TI Apiaká-Kaiabi in the Rio dos Peixes.

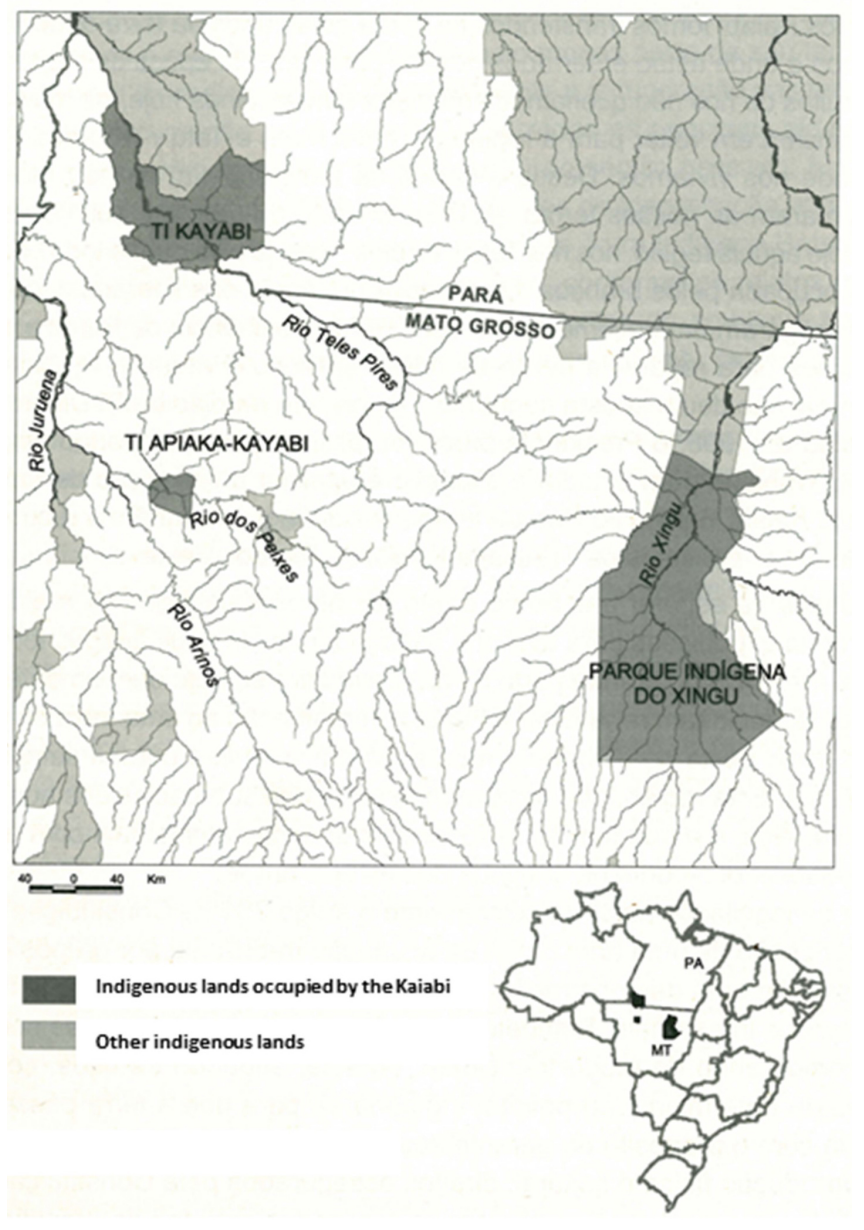

Weaving is an artistic social-ecological practice of special importance among the Kawaiwete, reflecting aspects of the group's history, cosmology, ecology, and social-economic organization. The repertoire of graphic designs represented in basketry and textiles may be understood as an immaterial cultural heritage, which perpetuates Kawaiwete collective memory and identity (Athayde et al. 2009).

The forced displacement and resettlement of the majority of the group from their original territory in the Teles Pires and Rio dos Peixes rivers to the upper Xingu region, between 1950 and 1966, followed by land demarcation and other political processes, resulted in overall social transformations and loss of access to strategic natural resources. This led to erosion of weaving 
Fig. 2. Methods and approaches used for creating, assessing, and communicating artistic knowledge by indigenous peoples and academic researchers participating in the Kaiabi Araa participatory action-research project.

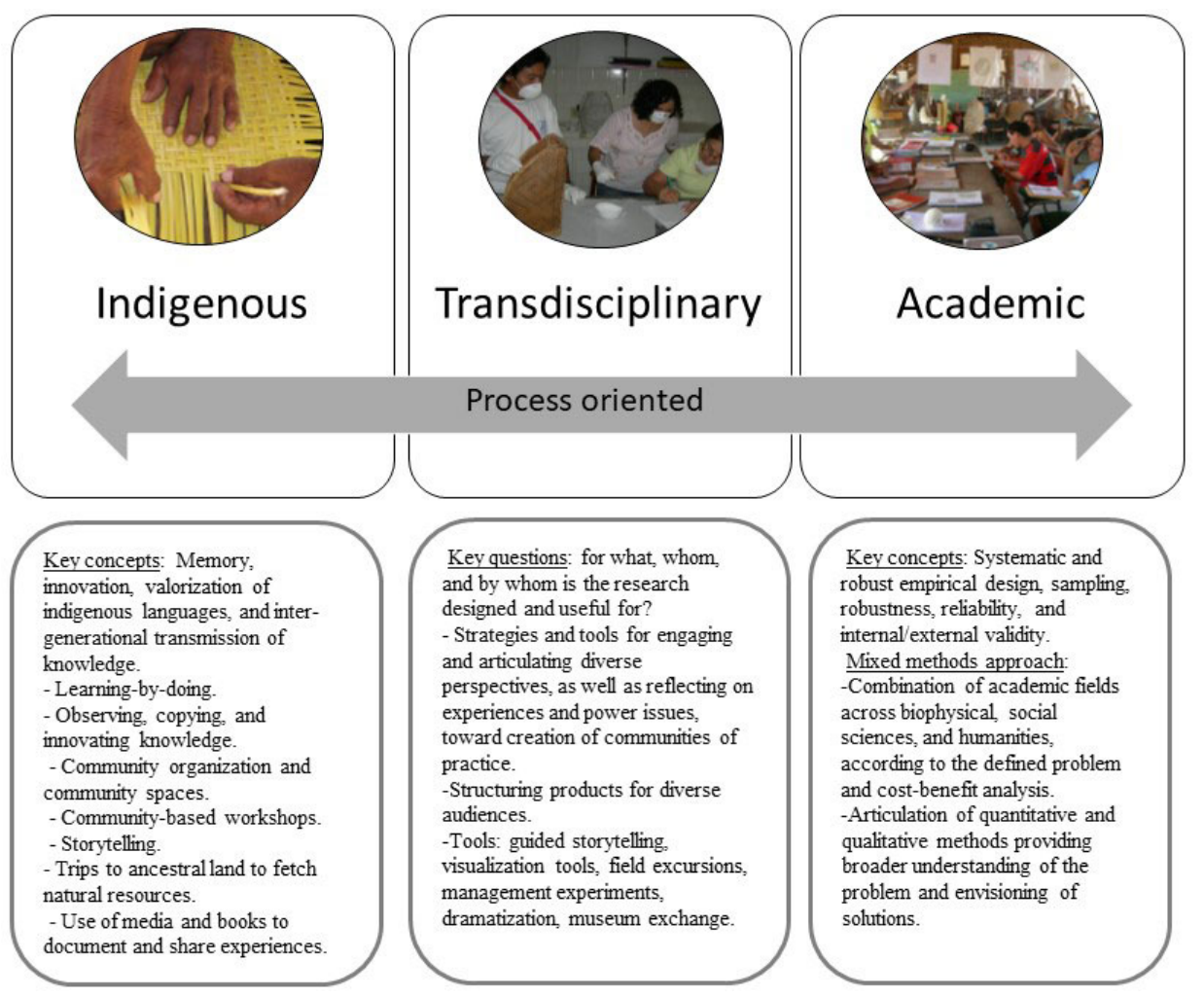

knowledge, to varying degrees, across the three Kawaiwete groups. A particularly important plant resource scarce in Xingu is "uruyp" (Ischnosiphon gracilis, Marantaceae; "arumã" in Portuguese), the main fibre used in Kawaiwete baskets. This herb forms clumps in swampy and periodically flooded areas throughout lowland Amazonia (Andersson 1977), but occurs only in scattered and small populations in the northwest, more humid, region of the park.

\section{Methodological approach}

The experience we present was part of the Xingu Program of the Instituto Socioambiental (ISA, a Brazilian NGO, http://www. socioambiental.org) and was carried out in partnership with indigenous organizations Associação Terra Indígena Xingu (ATIX) and Kaiabi Association in the Teles Pires area (Kawaip) among four Kawaiwete communities, across three Kawaiwete lands with distinct social-ecological contexts: two in Xingu Park (Capivara and Tuiarare villages), one in Rio dos Peixes village (Apiaká-Kaiabi indigenous land) and one in Kururuzinho village (Kayabi indigenous land on the Teles Pires River).

The problem was initially presented to us by Kawaiwete leaders, concerned about the erosion of artistic knowledge among men and women, as well as about environmental constraints linked to availability and management of natural resources, with a focus on the arumã plant used in basketry weaving by men (Ischnosiphon gracilis) and the cultivated native cotton (Gossypium barbadense) used in textiles weaving by women. Kawaiwete basketry encounters its greatest expression in the twilled-plaited baskets made by men and used by women, exchanged, or sold to nonindigenous persons. After the transfer of the majority of the group to Xingu Park in the 1970s, women started to weave basketry designs into different woven objects, such as hammocks, straps for carrying babies, and, more recently, on bags commercialized to nonindigenous persons (Ribeiro 1984/1985).

Aiming to revitalize weaving knowledge across geographically separated groups, a group of men and women from the Tuiararé village in Xingu and the Kururuzinho village in Teles Pires, developed a participatory action-research, community-based project that lasted seven years (named Kaiabi Araa, or design of the Kaiabi). It included the organization of weaving workshops for men and women involving teachers or experts and students from several age groups in villages in the Xingu and Teles Pires rivers. It was funded by the Indigenous Peoples Demonstrative Projects (PDPI) from the Pilot Program to Conserve the Brazilian Rain Forest (PPG7), and it was implemented by indigenous communities in partnership with ISA and ATIX.

Activities for collaborative research and knowledge integration included the design, coordination, and integration of two broader sets of methods and tools: strategies developed by indigenous peoples, and methods and approaches from academic fields in the biophysical and social sciences (Fig. 2). Transdisciplinary methods and tools enhanced the integration of both sets of strategies and methods, and included integration of efforts and 
knowledge among practitioners, NGOs, researchers, and indigenous communities. Research questions were defined jointly by indigenous communities, researchers, and practitioners, and results were integrated to practical activities for knowledge revitalization and environmental management.

Academic research was conducted in collaboration with the community-based project through a mixed methods quantitativequalitative approach, including ethnographic and ethnoecological methods for data collection characterizing diverse dimensions of weaving knowledge among men and women. Semistructured interviews were conducted among 224 people (110 men and 114 women) over 15 years of age across 4 villages, 2 of them located in the Xingu indigenous land (Tuiararé and Capivara), 1 in the Apiaká-Kaiabi indigenous land (Rio dos Peixes village) and the other in the Kayabi indigenous land in the Teles Pires River (Kururuzinho village). A comprehensive catalog containing photos of 36 coded basketry designs was used in the interviews.

To assess the impact of the Kaiabi Araa project on the knowledge of basketry designs, we conducted a comparative longitudinal assessment of the number of basketry designs woven by men in Tuiararé (with project) and Capivara (no project) villages before and five years after the Kaiabi Araa cultural revitalization project was developed. A binomial proportion comparison (Ott and Longnecker 2010) was performed to compare the proportion of designs known by men in Capivara and Tuiararé villages between 2002 and 2007 within and between villages. The significance level used was 0.05 .

\section{RESULTS}

Methods and strategies for coproduction of knowledge

During the eight-year involvement in the Kaiabi Araa cultural revitalization project, we found that the use of a mixed methods approach, in which indigenous strategies were allowed and encouraged to emerge along with academic research, was an important step toward coproduction of knowledge that was relevant for both indigenous peoples and for the development of transdisciplinary theory on indigenous artistic knowledge. Products of this initiative included an indigenous monograph for the conclusion of a bachelor's degree in literature by an indigenous teacher and leader, technical reports presented to funding agencies, a Master's thesis, a doctoral dissertation, educational and academic materials, national and international awards, and a video documentary (Kaiabi Araaa video filming available at https://vimeo.com/26896495).

Indigenous leadership and participation in defining research questions, carrying out interviews, and organizing weaving workshops was a key element in this long-term experience. However, we learned that indigenous leadership in development and community-based projects does not happen overnight. The long-term access to financial, technical, and intercultural educational support provided by ISA and international funding, were critical to build the social capital required for indigenous self-determination and leadership observed among the Kawaiwete from the Xingu Park, in contrast with the other two groups.

The process of integration of academic research methods with learning-by-doing methods developed by indigenous peoples in the weaving workshops was challenging, because the ways through which knowledge is approached by science and by indigenous communities has fundamental epistemological differences. Thus, knowledge and learning needed to be explicitly negotiated and translated during the project activities. Indigenous knowledge is produced and validated through collective memory, social order, and experience. Scientific knowledge is produced through hypotheses testing, systematic procedures, and theory development. Indigenous workshops were viewed by researchers as quite disorganized and nonstructured, whereas graphs and tables produced by systematic collection of information by researchers were difficult to understand for indigenous persons.

Curiously, quantitative results produced by statistical analyses of the distribution and transmission of weaving knowledge across genders and geographic groups was a powerful outcome appropriated by indigenous peoples. Leaders argued for the need to revitalize knowledge of threatened designs and to combine traditional ways of knowledge transmission with new ones, such as the promotion of workshops and the use of books with photographs. The books now may play the role of snake's skins mentioned in the myth of the origin of basketry designs (an excerpt of the myth is presented in the next section), keeping a visual memory or catalogue of designs that can be copied and passed on to future generations by more experienced weavers.

\section{Between art and science: living objects, threatened knowledge}

From the interviews with elders and shamans, we found that in Kawaiwete cosmology, objects enacting collective artistic knowledge are living beings. Learning and creating, in Kawaiwete society, are related to shamanism. The skillful basket weaver, named Tuiarare, was also a great shaman and, according to a myth, learned to weave designed baskets by stealing a piece of basket from the house of a snake, a supernatural being. (Fig. 3; Athayde 2006).

The myth goes as follows:

Tuiarare, the great ancestral hero, creator of Kawaiwete people, went on an expedition to Xingu River (Wywa'y) to collect a kind of bamboo (canabrava, Gynerium sagitatum) to make arrows. He walked around a lot, and he discovered many natural resources important for the Kawaiwete people during his travels. On his way back home, he arrived at a village; it was the "snake" village. After discussing with the snake for one entire night, he spoke the name of a great hawk known as a snake eater, and then he left the house carrying a piece of designed basket, from which he learnt how to weave baskets and transmitted this learning to the Kawaiwete people (Athayde 2006).

The acts of creation, discovery, or dreaming are intimately linked to symbolic development, creation of new designs or painting patterns, and naming beings. In a sense, then, artistic objects are alive, they are not objects, but subjects.

The materials used in basketry and textiles are also live beings who have their own spirits or masters: the arumã plant, the main fiber used in designed basketry, has its own spirit, as does the cotton used by women to weave hammocks, bags, and belts. Cotton seeds were "born" from a woman's vagina during a shaman's prayer. Traditional mechanisms for learning to weave among men and women involve observation, copying, doing, 
Table 1. Outcomes of the Kaiabi Araa project workshops. Objects and designs produced by the participants in Tuiararé and Kururuzinho villages from 2004 and 2005.

\begin{tabular}{|c|c|c|c|c|}
\hline \multirow[t]{2}{*}{ Products } & \multicolumn{3}{|c|}{ Workshops } & \multirow[t]{2}{*}{ Total } \\
\hline & Kururuzinho 2004 & Tuiararé 2004 & Tuiararé 2005 & \\
\hline Designed baskets & 20 & 31 & 25 & 76 \\
\hline Panaku basket (backpack type) & 0 & 0 & 1 & 1 \\
\hline Designed hammock & 2 & 1 & 1 & 4 \\
\hline Simple hammock & & 0 & 1 & 1 \\
\hline Stripe for carrying babies & 3 & 5 & 6 & 14 \\
\hline Woven bags & 0 & 0 & 9 & 7 \\
\hline
\end{tabular}

undoing, and repeating (Crickmay 2002, Wyndham 2002, Zarger 2002). For the designs, it also entails mastering a particular system of mathematics and counting.

Fig. 3. Drawing depicting the myth of origin of basketry designs for the Kawaiwete people. The ancestral hero and shaman Tuiararé steals a piece of an anaconda skin, from which he learned how to weave designed baskets and taught the Kawaiwete people. Drawing by Loyvare Jr Kaiabi, Aiporé village, 06/25/1999. Source: adapted from Athayde (2006).

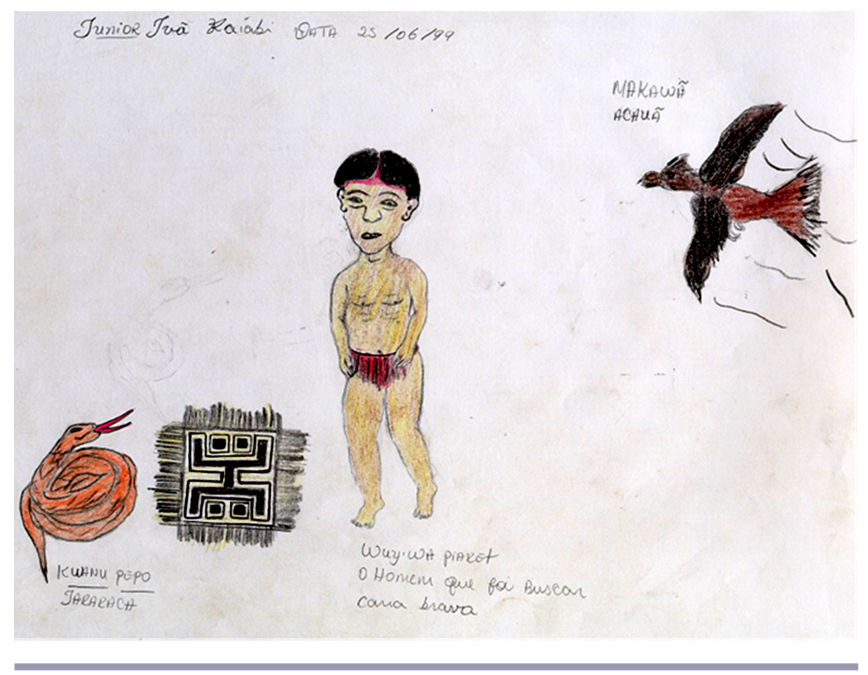

The different designs reproduced in the baskets and textiles express a symbolic language that is unique to the Kawaiwete people. Austrian anthropologist Georg Grünberg identified and documented 12 graphic designs for the Kawaiwete baskets during his work with the group in the 1960s (Grünberg and Grünberg 1967). His photographic documentation was repatriated to the Kawaiwete by us, through a kind donation by the Museum of Cultures of Basil, Switzerland. Additional photos used in the catalogue were donated by other national and international ethnographic museums.

We found that artistic knowledge of basketry designs was heterogeneously distributed among the Kawaiwete and across the three geographically separated groups (Athayde et al. 2009). Although artistic knowledge has been maintained in the Capivara and Tuiararé communities in Xingu Park, it has been eroded in the Rio dos Peixes and Kururuzinho villages in the ancestral territory.
Continuity and change: innovation and social-ecological resilience A total of 67 people participated in the 3 indigenous-led workshops of the Kaiabi Araa project in the Tuiarare and Kururuzinho villages; of these, 11 were basketry teachers, 7 were textiles teachers, 27 were male apprentices, and 22 were female apprentices. It was the first time that many youth living in the ancestral land (Teles Pires River) had the opportunity to learn with Xingu teachers, especially the young women. The project also involved teachers followed the work of the apprentices after the workshops, which was very important for fixating the learned techniques. A summary of the items produced for the three workshops is presented in Table 1. The collection of 76 baskets produced included 13 graphic designs, including the most complex ones known as "ta'agap" (mythical figure), which are threatened with disappearance (Athayde et al. 2009). From the interviews conducted with 114 men across 3 indigenous lands, we found that only 2 elders (from Xingu) could still weave 20 of the 36 designs, which shows that the knowledge of most sophisticated designs has been eroding at a fast pace and had not been passed on to younger generations.

We conducted a comparative longitudinal assessment of the number of basketry designs woven by men in the Tuiarare (with project) and Capivara (no project) villages before and five years after the Kaiabi Araa cultural revitalization project. We found that the project had a significant effect $(\mathrm{P}<0.001)$ on the number of basketry designs learned by men in the participating village compared with the village that was not involved (Appendix 1; Fig. 4). For 25 of the 36 designs, knowledge increased after the weaving workshops; for 8 designs knowledge remained the same, and for 7 designs knowledge decreased from 2002 to 2007. Some of the more difficult designs were still threatened with disappearance, as were the complex names given to them. From the interviews repeated with the same male participants before and after the project was conducted, we registered the mention of a new "manyto-many" way of learning, from the workshop, which had not been reported by the participants in 2002 (Fig. 5).

Throughout the Kaiabi Araa project, we documented evidence of social-ecological innovation in modes of creation and in the transmission of artistic knowledge among the Kawaiwete, including: (1) transmission of techniques across genders; (2) borrowing and modifying techniques from neighboring cultures; (3) carrying out management experiments and using substitute plant species and industrial cotton for weaving baskets and textiles; (4) connecting with museums for cultural repatriation; (5) using media (books, films, and photos) to revitalize traditional 
knowledge; and (6) enhancing modes of learning and transmission through community-based cultural revitalization projects. In Xingu, aiming to protect the valued knowledge and the diversity of graphic designs woven in baskets, men taught women how to weave them in textiles (hammocks, straps for carrying babies, bags) using a technique borrowed from the Yudja indigenous people (Ribeiro 1984/1985). Men also transferred the graphic designs to body painting and to other objects, such as wooden-carved benches and beaded bracelets.

Fig. 4. Comparison of the percentage of men capable of weaving basketry designs in 2002 and 2007, showing the impact of the action-research project Kaiabi Araa. Designs are coded according to the catalogue used for the semistructured interviews carried out with same men in two villages. Photos by: Simone Athayde, Georg Grünberg, and donations from The Museum of Cultures (Basel, Switzerland) and Museum of Archaeology and Etnography of Sao Paulo (MAE/USP).

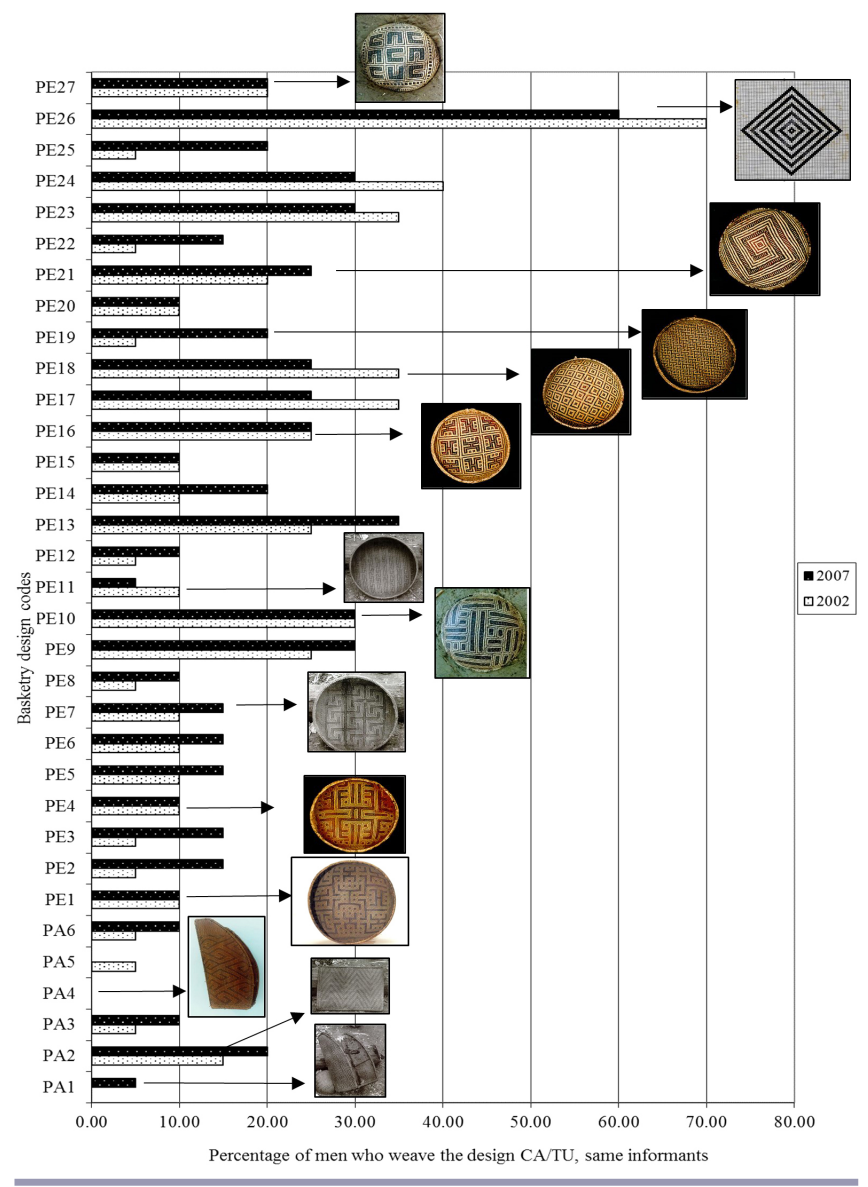

To cope with the scarcity of raw materials used in basketry weaving due to environmental change resulting from geographical displacement, men have used at least six plant substitutes for the arumã plant (Athayde et al. 2006). Additional innovation mechanisms include the revitalization of forgotten designs through visual repatriation of photos archived in museum collections, and using books and media to reproduce designs through photographic documentation and video filming.
Fig. 5. Comparison of ways of learning to weave baskets through a longitudinal assessment done before (2002) and after (2007) the Kaiabi Araa project, among men from Capivara and Tuiararé villages in Xingu. Learning from the workshop was an important category reported by men and women who participated in the indigenous-led weaving workshops.

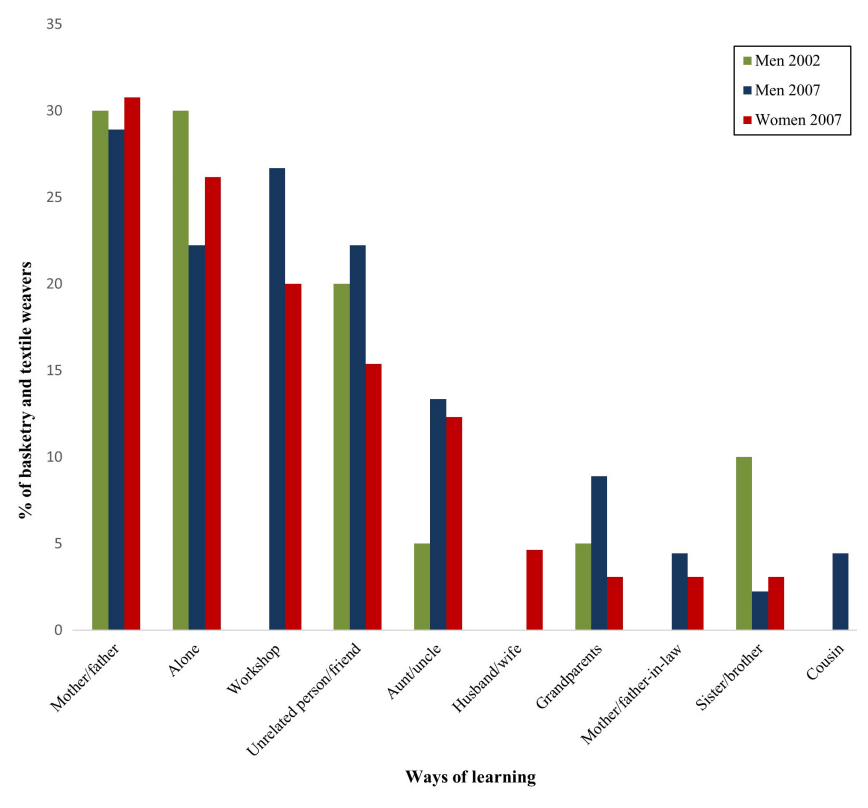

During the Kaiabi Araa workshops, planned and executed by indigenous communities, the main learning model was a collaborative many-to-many mode of learning, in which many teachers, elders or not, independent of age or kinship, taught many students and could also learn from each other. Teachers and students might come from different places, reinforcing their collective identity, and creating closer ties between geographically separated groups. Collaborative learning happens in a community of practice, whose members are consciously participating in a learning activity with a shared sense of group identity (Bowser and Patton 2008). This type of workshop entailed more freedom to innovate and learn, providing social learning opportunities otherwise unavailable in the traditional knowledge system. It documents new possibilities of generational interplay in knowledge retention and innovation, including older persons learning from younger teachers, and the expansion of options for learning from specialists in one technique or certain basketry types or designs (Fig. 6).

\section{DISCUSSION}

Coproduction of knowledge between different epistemological systems requires openness to appreciate other ways of learning and understanding the world. Miller et al. (2008) proposed the term "epistemological pluralism," as a philosophical principle that recognizes multiple valid and valuable ways of knowing, in which a continuous process of negotiation occurs between researchers and stakeholders. Among the Kawaiwete, as well as among other indigenous peoples, knowledge domains defined by science may be considered unfitting: art and science coexist within 
indigenous traditions. A shaman, for instance, might play both the role of an artist, creating knowledge from dreaming and connecting with spirits, and the scientist, learning-by-doing through trial and error, which can be compared to hypothesis testing. According to Erren et al. (2013), folk knowledge held by nonscientists, such as indigenous persons, is manifested in common sense, which might be compared to the scientific research process. This knowledge results from powerful tests of hypotheses by many individuals across time and space.

Fig. 6. Highlights from the Kaiabi Araa project workshops. A. and B. men learning-by-doing in a community of practice; some young men are using the book with basketry photo catalogue. C. Basket showing the Kururu'i design (little frog). D. More (Kaiabi teacher, Tuiararé village) weaving the Kururu'i design on a strap for carrying babies. Photos by: Simone Athayde.
A

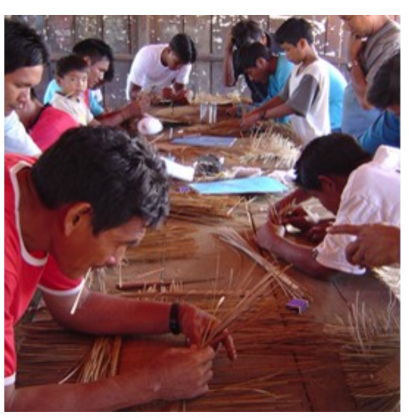

C

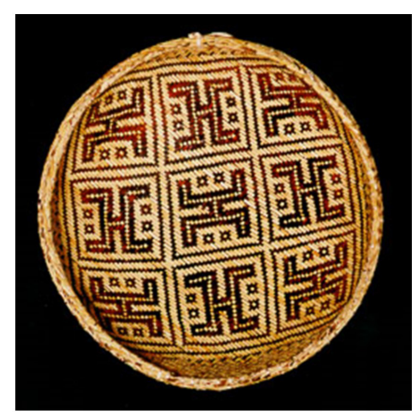

B

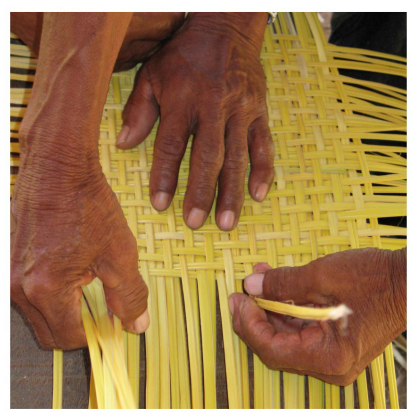

D

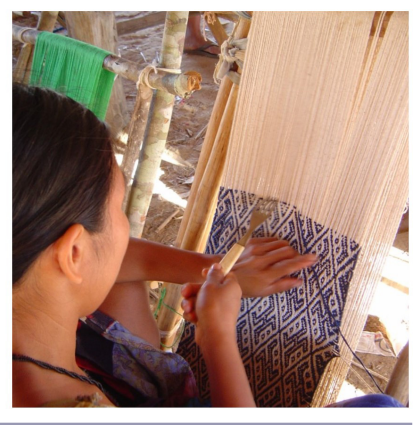

Indigenous thought is founded on a demand for order, like the counting system employed in basketry weaving and the detailed names given to the designs. Lévi-Strauss (1966:6) stated that "through the properties common to all thought we can most easily begin to understand forms of thought which seem very strange to us." Kawaiwete ways of interacting with the world are intertwined and solidified in a basket-being. Thus, the conceptualization of a social-ecological system by a scientist and an indigenous person or an artist may be quite different. Capturing and translating local knowledge needs to be done by specifying epistemological and theoretical orientations and choices (Evely et al. 2008). Indigenous knowledge may not be viewed as a panacea or abstract theory that exists apart from its context. Awareness about the diverse dimensions and processes involved when attempting to frame and bound indigenous knowledge is important to avoid narrowing the problem and trying to objectify what is subjective and fluid (Crane 2010). We thus claim for a deeper awareness in attempting to conceptualize indigenous knowledge by western science, being cautious about framing ecological knowledge dislocated from its context, separated from other domains, and neglecting its adaptive nature in contact with other knowledge systems, indigenous or nonindigenous (Berkes et al. 2000, Brosius 2004).

The social-ecological valuation of diversity and complexity, placed by the Kawaiwete, is not restricted to baskets, but extends to other domains, notably crops. Just as basket makers derive considerable prestige from their mastery over a diversity of designs, some Kawaiwete men and women have accumulated a surprising diversity of crops. As with basketry, the ability to generate new forms, whether weaving designs or crop varieties, is linked to shamanistic power and agency (Guss 1989, Silva 2004). Such as in other areas of Amazonia, shamanism still seems to play a crucial role in the maintenance and generation of biological and cultural diversity (Salick et al. 1997). Van Velthem (2003) argued that the multiplicity of representations, techniques, and meanings encoded in indigenous people's artistic material manifestations should lead us to talk about indigenous "arts" in the plural, commonly referred to as indigenous art in the singular. Among the Wayana people from the Brazilian Amazon, van Velthem (2003) found that the elements of form, function, and decoration were intertwined with present and primeval times and with the individual and his social group, having real and symbolic transformative capacities. The object can transform animals and plants into food (e.g., baskets, graters, and squeezers), youth into adults (e.g., earrings, tattoos, and piercings), and ordinary men into supernatural beings (e.g., masks, adornments, and other ritual objects)

The main lessons learned and implications from this experience for participatory action-research and sustainable development are:

- The ecological dimension of weaving among the Kawaiwete opened our understanding, as academics, to the multiple connections between ecological and social resilience among resource-dependent indigenous communities. These connections manifest through cosmology and history (myths, stories, spiritual connections, beliefs), natural resource use, and management techniques and practices, i.e., resources used in weaving are spread across ecosystems and some, such as cotton, are dependent on domestication, soil fertility, and social practices (such as women's stewardship) for their perpetuation. In the case of forest resources, displacement, climate change, and territorial encroachment pose risks to the sustainability of sensitive resources, such as the arumã plant.

- Coproduction of knowledge among academics and indigenous peoples might occur through hybrid natural resource management practices, combining indigenous knowledge (e.g., seasonality, collection and harvesting practices, multiple-site exploitation, rotation) with agricultural-ecological knowledge (species characteristics and needs, resource inventories, transplanting and monitoring practices, etc.). An interdisciplinary approach is called upon for academics to enable the understanding and 
respect of cultural and ecological specificities and complexity of indigenous knowledge domains (Athayde et al. 2006, Raymond et al. 2010). In this case, it entailed the articulation between academic fields, such as cultural anthropology, botany, and ecology.

- The important role played by diverse community members, such as indigenous leaders, shamans, and women, in guiding the research agenda and providing specialized knowledge on the diverse dimensions and social contexts of weaving as a social-ecological practice need to be considered in research projects and policies oriented toward local empowerment and change.

- The risk of committing "epistemic injustice," or subjugation and misrepresentation of indigenous knowledge by academics needs to be recognized and addressed. Linguistic and epistemic diversity across cosmologies make the process of coproduction of knowledge especially difficult and challenging. According to Foucalt (1991) "regimes of truth" and power are the result of scientific discourse and institutions, and are reinforced (and redefined) constantly through the education system, the media, and the flux of political and economic ideologies. The same dynamics may also be extended to power dynamics within and across academic disciplinary fields.

- The innovations developed by the Kawaiwete to curb the erosion of weaving knowledge of graphic designs testify to the important role of human agency in driving cultural transmission, leading to the resilience of desired cultural traits, and related natural resources, under threat of disappearing. The continued use of the mixed many-tomany mode of learning during community-based workshops, in addition to the traditional modes of knowledge transmission, may lead to enhanced learning and innovation among participating communities, in contrast with groups adopting more conservative traditional transmission modes (Hewlett and Cavalli-Sforza 1986, Hosfield 2009). Our study shows the role and importance of the interplay between memory and innovation for the sustainability of indigenous social-ecological domains and practices.

- The combination of qualitative and quantitative methods helped to shed light on contemporary changes in patterns of knowledge transmission informed by new institutions and social roles such as community-based projects, collaborative research with academics, intercultural schools, indigenous associations, and the role of NGOs. Applying systematic and rigorous methods and tools to document both the process of knowledge engagement and the problem under investigation was valuable to both academic and indigenous communities.

\section{CONCLUSION}

Learning is the process through which information, experience, instruction, or study becomes knowledge or skills. Learning is a fundamental aspect of collaborative research, and as such, methods to enable, enhance, and reflect on mutual learning are critical for both coproduction of knowledge and the advancement of transdisciplinary theory and practice in sustainability science. From this experience, a critical question for building theory and methods in sustainability science may be: what forms of knowledge does humanity need to advance to sustain the world for future generations?

Methods for coproduction of knowledge between science and society require openness, patience, creativity, and interactivity to allow meaningful engagement and on-the-ground application toward problem resolution, whatever the problem defined by participating actors. Thus, such a methodological approach needs to be designed considering strategies, tools, and other methods that go beyond the traditional scientific methods used for research in biophysical, social sciences, and the humanities. If we are to go beyond the "sequestration" of indigenous knowledge by science, a reflective and interactive approach to knowledge production and application must be advanced in collaborative research projects (Bohensky and Maru 2011).

Understanding and supporting indigenous strategies to adapt to changing social-ecological conditions is critical to inform management and political decisions for securing the integrity of indigenous lands and the ecosystem services they provide to humanity. Studies on indigenous knowledge systems cannot ignore the role that western institutions, including markets, schools, projects, and associations might be playing in changing patterns of knowledge distribution and transmission. Considering the growing mobilization and participation of indigenous peoples in the development and conservation political arena, integrative studies will also inform and enhance cultural sharing, memory, dialogue, new technologies, and notably, the persistence of indigenous practices, communities, and identities in the face of rapid change.

Responses to this article can be read online at: http://www.ecologyandsociety.org/issues/responses. $\mathrm{php} / 9323$

\begin{abstract}
Acknowledgments:
Funding for this research was provided by $C N P q$ Doctoral Fellowship to $S A$ (Brazilian National Council for Scientific and Technological Development); Tropical Conservation and Development Program field grant, University of Florida (TCD/ UF); Amazon Conservation Leadership Initiative (ACLI/UF); School of Natural Resources and the Environment (SNRE/UF); and American Association of University Women (AAUW). We acknowledge Instituto Socioambiental (ISA), Xingu Indigenous Land Association (ATIX), Tapawia Association, and Itaok Association for their support. Publication of this article was funded by the University of Florida Open Access Publishing Fund (UFOAP).
\end{abstract}

\section{LITERATURE CITED}

Andersson, L. 1977. The genus Ischnosiphon (Marantaceae). Opera Botanica 43:1-113.

Athayde, S. 2006. O livro da cestaria Kaiabi - yrupema re je mu'e. Instituto Socioambiental, Canarana, Brazil. [online] URL: http:// ufdcimages.uflib.ufl.edu/IR/00/00/06/92/00001/Athayde_Livro_Cestaria Kaiabi 2006.pdf 
Athayde, S., A. Kaiabi, K. Y. Ono, and M. Alexiades. 2009. Weaving power: displacement and the dynamics of basketry knowledge amongst the Kaiabi in the Brazilian Amazon. Pages 249-274 in M. N. Alexiades, editor. Mobility and migration in Indigenous Amazonia: contemporary ethnoecological perspectives. Berghahn Books, London, UK.

Athayde, S. F. de, G. M. da Silva, J. Kaiabi, M. Kaiabi, H. R. de Souza, K. Ono, and E. M. Bruna. 2006. Participatory research and management of arumã (Ischnosiphon gracilis [Rudge] Köern., Marantaceae) by the Kaiabi people in the Brazilian Amazon. Journal of Ethnobiology 26(1):36-59. http://dx.doi.org/10.2993/0278-0771 (2006)26[36:PRAMOA]2.0.CO:2

Athayde, S., J. R. Stepp, and W. C. Ballester. 2016. Engaging indigenous and academic knowledge on bees in the Amazon: implications for environmental management and transdisciplinary research. Journal of Ethnobiology and Ethnomedicine 12(26). http://dx.doi.org/10.1186/s13002-016-0093-Z

Berkes, F., and M. K. Berkes. 2009. Ecological complexity, fuzzy logic, and holism in indigenous knowledge. Futures 41(1):6-12. http://dx.doi.org/10.1016/j.futures.2008.07.003

Berkes, F., J. Colding, and C. Folke. 2000. Rediscovery of traditional ecological knowledge as adaptive management. Ecological Applications 10(5):1251-1262. http://dx.doi. org/10.1890/1051-0761(2000)010[1251:roteka]2.0.co;2

Berkes, F., C. Folke, and M. Gadgil. 1994. Traditional ecological knowledge, biodiversity, resilience and sustainability. Pages 281-299 in C. A. Perrings, K.-G. Mäler, C. Folke, C. S. Holling, and B.-O. Jansson, editors. Biodiversity conservation problems and policies. Springer Science and Business, Dordrecht, Germany.

Bohensky, E. L., and Y. Maru. 2011. Indigenous knowledge, science, and resilience: what have we learned from a decade of international literature on "integration"? Ecology And Society 16 (4):6. http://dx.doi.org/10.5751/es-04342-160406

Bowser, B. J., and J. Q. Patton. 2008. Learning and transmission of pottery style: women's life histories and communities of practice in the Ecuadorian Amazon. Pages 105-129 in M. T. Stark, B. J. Bowser, and L. Horne, editors. Cultural transmission and material culture: breaking down boundaries. University of Arizona Press, Tucson, Arizona, USA.

Brosius, J. P. 2004. What counts as local knowledge in global environmental assessments and conventions? Pages 129-144 in W. V. Reid, F. Berkes, T. J. Wilbanks, and D. Capistrano, editors. Bridging scales and epistemologies: linking local knowledge and global science in multi-scale assessments. Island, Washington, D. C., USA.

Chambers, R. 1994. The origins and practice of participatory rural appraisal. World Development 22(7):953-969. http://dx.doi. org/10.1016/0305-750x(94)90141-4

Chernela, J. 2008. Translating ideologies: tangible meaning and spatial politics in the Northwest Amazon of Brazil. Pages 130-149 in M. T. Stark, B. J. Bowser, and L. Horne, editors. Cultural transmission and material culture. University of Arizona Press, Tucson, Arizona, USA.
Crane, T. A. 2010. Of models and meanings: cultural resilience in social-ecological systems. Ecology and Society 15(4):19. [online] URL: http://www.ecologyandsociety.org/vol15/iss4/art19/

Crickmay, L. 2002. Transmission of knowledge through textiles: weaving and learning how to live. Pages 40-55 in H. Stobart and R. Howard, editors. Knowledge and learning in the Andes: ethnographic perspectives. Liverpool University Press, Liverpool, UK. http://dx.doi.org/10.5949/liverpool/9780853235187.003.0003

Edwards, K., C. Lund, S. Mitchell, and N. Andresson. 2008. Trust the process: community based researcher partnerships. Pimatisiwin 6:187-200. [online] URL: http://www.pimatisiwin. com/uploads/823571025.pdf

Erren, T. C., M. S. Koch, and V. B. Meyer-Rochow. 2013. Common sense: folk wisdom that ethnobiological and ethnomedical research cannot afford to ignore. Journal of Ethnobiology and Ethnomedicine 9(1):80. http://dx.doi. org/10.1186/1746-4269-9-80

Etmanski, C., and M. Pant. 2007. Teaching participatory research through reflexivity and relationship: reflections on an international collaborative curriculum project between the Society for Participatory Research in Asia (PRIA) and the University of Victoria (UVic). Action Research 5(3):275-292. http://dx.doi.org/10.1177/1476750307081018

Evely, A. C., I. Fazey, M. Pinard, and X. Lambin. 2008. The influence of philosophical perspectives in integrative research: a conservation case study in the Cairngorms National Park. Ecology and Society 13(2):52. http://dx.doi.org/10.5751/ es-02679-130252

Foucault, M. 1991. Discipline and punish: the birth of the prison. Penguin, London, UK.

Freire, P. 1970. Cultural action for freedom. Harvard Educational Review and Center for the Study of Development and Social Change, Cambridge, Massachusetts, USA.

Gadgil, M., F. Berkes, and C. Folke. 1993. Indigenous knowledge for biodiversity conservation. Ambio 22(2-3):151-156.

Gibbons, M., C. Limoges, H. Nowotny, S. Schwartzman, P. Scott, and M. Trow. 1994. The new production of knowledge: the dynamics of science and research in contemporary societies. Sage, Thousand Oaks, California, USA.

Grünberg, F., and G. Grünberg. 1967. Die materielle kultur der Kaiabi-indianer. Archiv für Völkerkunde 21:27-89.

Guss, D. M. 1989. To weave and sing: art, symbol, and narrative in the South American rain forest. University of California Press, Berkeley, California, USA.

Heckenberger, M. J., J. C. Russell, J. R. Toney, and M. J. Schmidt. 2007. The legacy of cultural landscapes in the Brazilian Amazon: implications for biodiversity. Philosophical transactions of the Royal Society of London. Series B 362(1478):197-208. http://dx. doi.org/10.1098/rstb.2006.1979

Hewlett, B. S., and L. L. Cavalli-Sforza. 1986. Cultural transmission among Aka pygmies. American Anthropologist 88 (4):922-934. http://dx.doi.org/10.1525/aa.1986.88.4.02a00100 
Hosfield, R. 2009. Modes of transmission and material culture patterns in craft skills. Pages 45-60 in S. Shenan, editor. Patterns and process in cultural evolution. University of California Press, Berkeley, California, USA.

Kates, R. W., W. C. Clark, R. Corell, J. M. Hall, C. C. Jaeger, I. Lowe, J. J. McCarthy, H. J. Schellnhuber, B. Bolin, N. M. Dickson, S. Faucheux, G. C. Gallopin, A. Grübler, B. Huntley, J. Jäger, N. S. Jodha, R. E. Kasperson, A. Mabogunje, P. Matson, H. Mooney, B. Moore, III, T. O'Riordan, U. Svedlin, K. A. Annan, D. W. Cash, S. C. Moser, C. Gibson, E. Ostrom, T. Ahn, T. J. Wilbanks, R. W. Kates, B. Bolin, H. J. Schellnhuber, G. Petschel-Held, G. Petschel-Held, H. J. Schellnhuber, T. Bruckner, F. L. Toth, K. Hasselmann, O. Varis, J. Jger, A. Grbler, N. Nakicenovic, D. G. Victor, E. A. Parson, W. C. Clark, L. H. Gunderson, C. S. Holling, S. S. Light, R. Brandom, S. Faucheux, C. Hue, S. Faucheux, M. O'Connor, G. Gallopn, S. Funtowicz, M. O'Connor, J. Ravetz, N. S. Jodha, A. Patt, W. Tuinstra, L. Hordijk, M. Amann, P. Matson, R. Naylor, and I. Ortiz-Monasterio. 2001. Sustainability science. Science 292(5517):641-6422. http://dx.doi.org/10.1126/ science. 1059386

Kates, R. W., T. M. Parris, and A. A. Leiserowitz. 2005. What is sustainable development?: goals, indicators, values, and practice. Environment: Science and Policy for Sustainable Development 47 (3):9-21. [online] URL: https://groups.nceas.ucsb.edu/sustainabilityscience/2010\%20weekly-sessions/session-2-09.20.2010-sustainabilityscience-and-sustainable-development/readings/Kates and Parris and_Leiserowitz_Envt_2005.pdf/view

Klein, J. T. 2008. Evaluation of interdisciplinary and transdisciplinary research: a literature review. American Journal of Preventative Medicine 35:S116-S123. http://dx.doi.org/10.1016/ j.amepre.2008.05.010

Lang, D. J., A. Wiek, M. Bergmann, M. Stauffacher, P. Martens, P. Moll, M. Swilling, and J. C. Thomas. 2012. Transdisciplinary research in sustainability science: practice, principles, and challenges. Sustainability Science 7(1):25-43. http://dx.doi. org/10.1007/s11625-011-0149-X

Lévi-Strauss, C. 1966. The savage mind. University of Chicago Press, Chicago, Illinois, USA.

Long, J. W., H. L. Ballard, L. A. Fisher, and J. M. Belsky. 2016. Questions that won't go away in participatory research. Society and Natural Resources 29:250-263. http://dx.doi. org/10.1080/08941920.2015.1024368

Mariella, P., E. Brown, M. Carter, and V. Verri. 2009. Triballydriven participatory research: state of the practice and potential strategies for the future. Journal of Health Disparities Research and Practice 3(2):41-58.

Martens, P. 2006. Sustainability: science or fiction? Sustainability: Science, Practice and Policy 2(1):36-41. [online] URL: https:// sspp.proquest.com/sustainability-science-or-fiction-f3429e $3 \mathrm{be} 00 \mathrm{f}$

Miller, T. R., T. D. Baird, C. M. Littlefield, G. Kofinas, F. S. Chapin, III, and C. L. Redman. 2008. Epistemological pluralism: reorganizing interdisciplinary research. Ecology and Society 13 (2):46. http://dx.doi.org/10.5751/es-02671-130246

Nicolescu, B. 2010. Methodology of transdisciplinarity - levels of reality, logic of the included middle and complexity.
Transdisciplinary Journal of Engineering and Science 1(1):19-38. [online] URL: http://www.basarab-nicolescu.fr/Docs_Notice/ TJESNo 112 2010.pdf

Ott, R. L., and M. T. Longnecker. 2010. Introduction to statistical methods and data analysis. Sixth edition. Duxbury, Belmont, Australia.

Pretty, J., B. Adams, F. Berkes, S. F. de Athayde, N. Dudley, E. Hunn, L. Maffi, K. Milton, D. Rapport, P. Robbins, E. Sterling, S. Stolton, A. Tsing, E. Vintinnerk, and S. Pilgrim. 2009. The intersections of biological diversity and cultural diversity: towards integration. Conservation and Society 7(2):100-112. http://dx.doi.org/10.4103/0972-4923.58642

Probst, K., J. Hagmann, M. Fernandez, and J. A. Ashby. 2003. Understanding participatory research in the context of natural resource management - paradigms, approaches and typologies. Network Paper 130. UK Department for International Development, London, UK. [online] URL: https://www.odi.org/ resources/docs/5194.pdf

Raymond, C. M., I. Fazey, M. S. Reed, L. C. Stringer, G. M. Robinson, and A. C. Evely. 2010. Integrating local and scientific knowledge for environmental management. Journal of Environmental Management 91(8):1766-1777. http://dx.doi. org/10.1016/j.jenvman.2010.03.023

Reason, P., and H. Bradbury. 2008. The SAGE handbook of action research: participative inquiry and practice. Sage, Thousand Oaks, California, USA. http://dx.doi.org/10.4135/9781848607934

Reed, M. S., A. C. Evely, G. Cundill, I. Fazey, J. Glass, A. Laing, J. Newig, B. Parrish, C. Prell, C. Raymond, and L. C. Stringer. 2010. What is social learning? Ecology and Society 15(4):r1. http:// dx.doi.org/10.5751/ES-03564-1504r01

Ribeiro, B. G. 1984/1985. Tecelãs Tupi do Xingu. Revista de Antropologia 27/28:355-402.

Ribeiro, B. G. 1987. A linguagem simbólica da cultura material. Pages 15-27 in D. Ribeiro, editor. Suma etnológica Brasileira. Volume 3. Arte Índia. Vozes, Petrópolis, Brazil.

Ross, N. 2004. Culture and cognition: implications for theory and method. Sage, Thousand Oaks, California, USA.

Salick, J., N. Cellinese, and S. Knapp. 1997. Indigenous diversity of cassava: generation, maintenance, use and loss among the Amuesha, Peruvian upper Amazon. Economic Botany 51(1):6-19. http://dx.doi.org/10.1007/bf02910400

Santos, B. de S. 2007. Beyond abyssal thinking: from global lines to ecologies of knowledges. Review 1:45-89.

Silva, G. M. 2004. O sistema agrícola Kaiabi. Pages 265-272in G. Grünberg, editor.Os Kaiabi do Brasil Central: história e etnografia. Instituto Socioambiental, São Paulo, Brazil.

Tress, B., G. Tress, and G. Fry. 2006. Defining concepts and the process of knowledge production in integrative research. From landscape research to landscape planning: aspects of integration, education and application 12(13):13-26.

van Velthem, L. H. 2003. O Belo é a fera. A estética da produção e da predação entre os Wayana. Alvim, Lisbon, Portugal. 
Wyndham, F. S. 2002. The transmission of traditional plant knowledge in community contexts: a human ecosystem perspective. Pages 549-560 in J. R. Stepp, F. S. Wyndham, and R. K. Zarger, editors. Ethnobiology and biocultural diversity: proceedings of the seventh international congress of ethnobiology. University of Georgia Press, Athens, Georgia, USA.

Zarger, R. K. 2002. Acquisition and transmission of subsistence knowledge by Q' eqchi' Maya in Belize. Pages 593-603 in J. R. Stepp, F. S. Wyndham, and R. K. Zarger, editors. Ethnobiology and biocultural diversity: proceedings of the seventh international congress of ethnobiology. University of Georgia Press, Athens, Georgia, USA. 
Appendix 1. Proportion comparison of the number of designs known among men in Capivara and Tuiararé villages before and after the development of the Kaiabi Araa project.

Village

Capivara - Tuiarare 2002

Tuiarare 2002-2007

Capivara 2002-2007

Capivara - Tuiarare 2007

$\begin{array}{rrcrcr}\pi 1 & \pi 2 & \Pi & \sigma \pi 1-\pi 2 & \mathrm{Z} & \text { P-value } \\ 0.458 & 0.542 & 0.500 & 0.072 & -1.155 & 0.248 \\ 0.426 & 0.574 & 0.500 & 0.064 & -2.305 & 0.021 \\ 0.473 & 0.527 & 0.500 & 0.073 & -0.733 & 0.463 \\ 0.412 & 0.588 & 0.500 & 0.065 & -2.722 & 0.007\end{array}$

* Codes: $\pi \mathrm{i}=$ proportion. $\Pi=$ overall proportion. $\sigma \pi 1-\pi 2=$ standard deviation of the difference between two proportions. $\mathrm{Z}=\mathrm{Z}$ statistics. 